British Microbiology Research Journal

13(4): 1-8, 2016, Article no.BMRJ.24405

ISSN: 2231-0886, NLM ID: 101608140

SCIENCEDOMAIN international

www.sciencedomain.org

\title{
Mineral Phosphate Solubilization in Burkholderia tropica Involves an Inducible PQQ-Glucose Dehydrogenase
}

\author{
Pamela Romina Bernabeu1, Sabrina Soledad García1, Gimena García Ferreyra1, \\ Verónica Inés Guidi ${ }^{1}$, María Lina Galar ${ }^{1}$, José Luis Boiardi ${ }^{1}$ \\ and María Flavia Luna ${ }^{1,2^{\star}}$ \\ ${ }^{1}$ Departamento de Química, Centro de Investigación y Desarrollo en Fermentaciones Industriales \\ (CINDEFI), UNLP, CCT-La Plata-CONICET, Facultad de Ciencias Exactas, Universidad Nacional de \\ La Plata, La Plata, Argentina. \\ ${ }^{2}$ Comisión de Investigaciones Científicas de la Provincia de Buenos Aires (CIC-PBA), Argentina.
}

Authors' contributions

This manuscript is the result of teamwork. Author PRB designed all the experiments and managed the analysis and discussion of results. Author SSG contributed with experiments in flasks and gluconic acid and phosphorous determinations and managed literature searches. Author MLG carried out the supervision of experiments in flasks and bioreactors in relation with enzyme activities measures. Authors GGF and VIG realized all the experiments in bioreactors and enzyme activities measures. Author JLB contributed with the discussion of results, organization and planning of the manuscript. Author MFL developed the experimental design, supervised the experiments and managed the analysis and discussion of results. All authors read and approved the final manuscript.

Article Information

DOI: $10.9734 / B M R J / 2016 / 24405$

Editor(s):

(1) Joao Lucio Azevedo, University of São Paulo, Department of Genetics, Brazil.

Reviewers:

(1) Rama Bhat, Mangalore University, India. (2) Eduardo Ortega, University of Havana, Cuba.

Complete Peer review History: http://sciencedomain.org/review-history/13635

Original Research Article

Received $19^{\text {th }}$ January 2016

Accepted $23^{\text {rd }}$ February 2016

Published 11 ${ }^{\text {th }}$ March 2016

\section{ABSTRACT}

Aims: The objective of this work was to provide knowledgement about the mechanism and regulation of the mineral phosphate solubilization in Burkholderia tropica. To this end, the expression of the direct extracellular oxidative pathway in $B$. tropica was studied using different culture approaches. 
Study Design: Plate assays and batch cultures in flasks and bioreactor were carried out in this study with B. tropica Mto-293 like target organism. The experiments were achieved at least three times with two repetitions per time.

Place and Duration of Study: Departamento de Química, Centro de Investigación y Desarrollo en Fermentaciones Industriales, UNLP, CCT-La Plata-CONICET, between November 2014-2015.

Methodology: Qualitative plate assays with different Carbon sources were carried out for the evaluation of Mineral Phosphate Solubilization phenotype. Batch cultures in flasks were carried out with different Carbon, Phosphorus and Nitrogen sources to determine quantitatively soluble phosphorus, gluconic acid and other ketoacids in the supernatants, and also PQQ-linked glucose and gluconate dehydrogenase activities in whole cells. Cultures with some of the conditions mentioned before were carried out in bioreactor specifically to control $\mathrm{pH}$.

Results: This organism was able to produce significant amounts of gluconic acid via the expression of a PQQ-GDH and also showed a significant activity of GaDH. However, the direct oxidative pathway was only observed under conditions of Phosphorus starvation and/or Nitrogen fixation.

Conclusion: The Mineral Phosphate Solubilization phenotype for $B$. tropica can be ascribed to the expression of the direct oxidative pathway which involves the expression of an active PQQ- linked glucose dehydrogenase. Nevertheless, this pathway is not expressed constitutively in this bacterium. Environmental conditions, like low $\mathrm{P}$ and $\mathrm{N}$ availability, led to an active extracellular glucose oxidation. Therefore, mineral phosphate solubilization in $B$. tropica involves an inducible pyrroloquinoline quinone-linked glucose dehydrogenase. These findings may contribute to the use of this bacterium as plant growth promoting bacteria reducing the dependence on chemical fertilizer.

Keywords: Burkholderia tropica; phosphate solubilization; PQQ-GDH; nitrogen fixation.

\section{INTRODUCTION}

Soils are typically abundant in a variety of organic and inorganic forms of insoluble Phosphorus $(P)$, but deficient in soluble forms of $P$ essential for plant growth. In order to avoid Pdeficiency in agricultural soils phosphate fertilizers are widely applied. However, a significant portion of added $P$ is rapidly immobilized as insoluble forms and becomes unavailable to plants [1]. Mobilization of $P$ by microbial action is a possible way to provide soluble $\mathrm{P}$ to plants. Many reports show that some soil bacteria solubilize insoluble minerals through the production of acids, increasing the availability of $P$ and other nutrients to plants in deficient soils [2]. Several bacterial genera have been reported to express "mineral phosphate solubilizing" (MPS) capacity such as Pseudomonas, Bacillus, Rhizobium, Burkholderia, Achromobacter, Agrobacterium, Microccocus, Aereobacter, Flavobacterium, Erwinia and Gluconacetobacter [3-5]. It is generally accepted that the expression of a direct extracellular oxidative pathway is the principal mechanism for MPS bacteria [5,6-8]. This pathway (also called nonphosphorylating oxidation) is widely distributed among Gramnegative bacteria. It involves the periplasmic oxidation of aldoses into the corresponding aldonic acid by the quinoprotein glucose dehydrogenase (PQQ-GDH) [9]. Gluconic acid is the most frequent agent responsible for the MPS phenotype and is often further oxidized to 2ketogluconic by action of a gluconate dehydrogenase $(\mathrm{GaDH})$ [10]. These strong organic acids produced by bacteria are considered to play a significant role in dissolve poorly soluble calcium phosphates present in soils [11-13]. Burkholderia spp. are considered promising candidates for been used as biofertilizers [14-17] and can be classified, according to Bashan and Holguin [18], as "plant growth promoting bacteria". Among the different capacities expressed by Burkholderia spp. leading to promote plant growth we can mention: $\mathrm{N}_{2}$ fixation, expression of 1-aminocyclopropane1-carboxylic acid deaminase activity, antagonism against different plant pathogenic fungi, production of siderophores and MPS capacity [19-21]. Nahas [22] reported that B. cepacia showed the highest MPS activity among 42 soil bacterial isolates. On the other hand, gluconic acid was identified as responsible for the dissolution of tricalcium phosphate by $B$. cepacia CC-A174 [23] and B. cepacia DA23 [24]. It has been reported that $B$. tropica possesses the most notable MPS capacity among the different Burkholderia spp. associated with plants [16]. But, the phosphate solubilizing mechanism and 
its regulation has not been mostly studied in this species. To this end we have studied the expression of the direct extracellular oxidative pathway in $B$. tropica growing under different culture conditions. It is shown that this organism was able to produce significant amounts of gluconic acid via the expression of a PQQ-GDH and also showed a significant activity of $\mathrm{GaDH}$. But, the direct oxidative pathway was only observed under conditions of P-starvation and/or Nitrogen fixation (nutritional and energy stress respectively).

\section{MATERIALS AND METHODS}

\subsection{Organisms and Maintenance}

Burkholderia tropica MTo-293 (ATCCBAA 569) [25] kindly provided by Dr. Jesús CaballeroMellado (Centro de Ciencias Genómicas, Cuernavaca, Morelos, México), was maintained at $4^{\circ} \mathrm{C}$ in LB medium [26] for monthly subcultures and in LGI medium [27] with $20 \%$ glycerol at $80^{\circ} \mathrm{C}$.

\subsection{Cultures and Growth Conditions}

Plate assays were carried out using the National Botanical Research Institute's phosphate medium (NBRIP) [28] containing $\left(\mathrm{L}^{-1}\right): \mathrm{Ca}_{3}\left(\mathrm{PO}_{4}\right)_{2}$ (TCP), $5.0 \mathrm{~g} ; \mathrm{MgCl}_{2} .6 \mathrm{H}_{2} \mathrm{O}, 5.0 \mathrm{~g} ; \mathrm{MgSO}_{4} .7 \mathrm{H}_{2} \mathrm{O}$, $0.25 \mathrm{~g} ; \mathrm{KCl}, 0.2 \mathrm{~g} ;\left(\mathrm{NH}_{4}\right)_{2} \mathrm{SO}_{4}, 0.1 \mathrm{~g}$; agar, $14.0 \mathrm{~g}$ and $10.0 \mathrm{~g}$ of different C-sources. Bacterial cultures of $B$. tropica with concentrations of approximately $1.10^{9} \mathrm{CFU} \mathrm{\textrm {mL } ^ { - 1 }}$ were centrifuged and resuspended in the same volume of saline solution $\mathrm{pH}$ 6.0. $50 \mu \mathrm{L}$ of these cell suspensions were plated onto NBRIP medium. Plates were observed two days after incubation at $30^{\circ} \mathrm{C}$. Formation of clearing zones around colonies indicated P-solubilization ability.

Batch cultures were performed employing the NBRIP liquid medium with 10 or $30 \mathrm{~g} \mathrm{~L}^{-1}$ of glucose or glycerol as carbon source, and $2.5 \mathrm{~g}$ $\mathrm{L}^{-1}$ of $\left(\mathrm{NH}_{4}\right)_{2} \mathrm{SO}_{4}$ (non-BNF conditions or $\mathrm{N}$ available conditions). TCP was replaced by $\mathrm{K}_{2} \mathrm{HPO}_{4}\left(2.0 \mathrm{~g} \mathrm{~L}^{-1}\right)$ in experiments with soluble $\mathrm{P}$. When the organism was grown under BNF conditions, $\left(\mathrm{NH}_{4}\right)_{2} \mathrm{SO}_{4}$ concentration was decreased to a starter dose of $0.132 \mathrm{~g} \mathrm{~L}^{-1}$ [27, 29]. Bacteria were grown at $30{ }^{\circ} \mathrm{C}$ in $1.0 \mathrm{~L}$ flasks containing $250 \mathrm{~mL}$ of liquid NBRIP medium (two flasks per treatment) on a rotary shaker stirred at 200 or 100 rpm for non-BNF or BNF, respectively. Negative controls (non-inoculated flasks) were carried out to quantify the solubilized $\mathrm{P}$ in the culture conditions regardless of microbial activity. B. tropica was also grown at $30^{\circ} \mathrm{C}$ in a $2.0 \mathrm{~L} \mathrm{LH}$ (Incelltech 210) bioreactor with a working volume of $1.0 \mathrm{~L}$. $\mathrm{pH}$ was automatically maintained at $6.0 \pm 0.1$ by addition of either $0.5 \mathrm{M}$ $\mathrm{NaOH}$ or $0.25 \mathrm{M} \mathrm{H}_{2} \mathrm{SO}_{4}$. Foam formation was prevented by automatic addition of an antifoam agent. Cultures were flushed with air (20 to $25 \mathrm{~L}$ $\left.\mathrm{h}^{-1}\right)$. These cultures were carried out on NBRIP liquid medium with glucose $\left(30 \mathrm{~g} \mathrm{~L}^{-1}\right)$ and $\mathrm{K}_{2} \mathrm{HPO}_{4}\left(2.0 \mathrm{~g} \mathrm{~L}^{-1}\right)$ under non-BNF conditions. Instantaneous additions of chloramphenicol (CP) (final concentration $200 \mu \mathrm{g} \mathrm{mL}^{-1}$ ) and $P Q Q$ (final concentration $10 \mu \mathrm{M}$, either alone or $2 \mathrm{~h}$ after $\mathrm{CP}$ pulse) were made at $18 \mathrm{~h}$ of bacterial growth (exponential phase). CP pulse was performed for inhibition of protein synthesis and addition of exogenous $P Q Q$ was made to reconstitute $P Q Q$ GDH apoenzyme.

\subsection{Analyses}

Samples of batch cultures were taken at 8-12 $\mathrm{h}$ intervals during 2 days for measurements of $\mathrm{pH}$, biomass dry weight [30], glucose consumption and product formation. Samples of batch cultures grown in medium with TCP were diluted 1:1 (v/v) using $0.1 \mathrm{M} \mathrm{HCl}$ to dissolve the residual insoluble phosphate and measured against a blank identically treated [31]. Samples were centrifuged $10 \mathrm{~min}$ at $10,000 \mathrm{~g}$ and the resulting supernatant was employed for glucose, gluconic acid and soluble $\mathrm{P}$ assays. Glucose concentrations in media and supernatants were determined with a glucose oxidase enzymatic kit (Wiener, Argentina). Gluconic and 2-ketogluconic acid production were determined in bacterial supernatant by High Performance liquid chromatography (HPLC) with a Hamilton PRPX300 (250 x 4,1 mm ID, $7 \mu \mathrm{m}$ pore size) column equipped with Waters 717 plus autosampler and UV detector. UV absorption was monitored at $210 \mathrm{~nm}$. The mobile phase was $\mathrm{H}_{2} \mathrm{SO}_{4} 5 \mathrm{mM}$ applied at a flow rate of $2.0 \mathrm{~mL} \cdot \mathrm{min}^{-1}$. Column temperature was maintained at $25^{\circ} \mathrm{C}$. Soluble $\mathrm{P}$ concentrations were measured by the method described by Clesscerl et al. [32].

\subsection{Enzyme Assays}

PQQ-GDH and gluconate dehydrogenase $(\mathrm{GaDH})$ in vitro activities were measured spectrophotometrically using 2,6-dichlorophenolindophenol (DCIP) as the electron acceptor and glucose or gluconate respectively as $\mathrm{C}$ sources $[33,34]$ Samples $(20 \mathrm{~mL})$ from batch cultures were taken during exponential growth phase (17-20 $\mathrm{h}$ of growth) and centrifuged for 10 minutes at $12,000 \mathrm{~g}$ at $4^{\circ} \mathrm{C}$. Cells were washed 
twice in phosphate buffer $10 \mathrm{mM}(\mathrm{pH}$ 6.0) containing $5 \mathrm{mM} \mathrm{MgCl}_{2}$ to a final concentration of $4.50 \mathrm{mg} \mathrm{mL}^{-1}$ dry weight. This washed cells suspension was employed to determine the PQQ-GDH activity in whole cells. The final concentration of cells in the reaction mixture was $0.10 \mathrm{mg} \mathrm{mL}^{-1}$ dry weight. When enzyme activity was measured in the presence of exogenous $P Q Q$, the mixture was preincubated for $15 \mathrm{~min}$ at $30^{\circ} \mathrm{C}$ with $100 \mathrm{mM} P Q Q$ in $10 \mathrm{mM} \mathrm{Na}{ }_{2} \mathrm{HPO}_{4}-5$ $\mathrm{mM} \mathrm{MgCl} 2$ prior to the addition of glucose.

\section{RESULTS}

\subsection{Plate Assays}

Qualitative estimation of $\mathrm{P}$ solubilization was performed in agar plates supplemented with TCP. The MPS phenotype was visualized by appearance of significant clearing halos around colonies of $B$. tropica in plates containing glucose, arabinose, galactose and xylose (all substrates of PQQ-GDH). In plates supplemented with glycerol, sodium gluconate, maltose and fructose, $B$. tropica showed growth but no appearance of solubilization zones (data not shown).

\subsection{Cultures}

No activity of PQQ-GDH could be found in batch cultures of $B$. tropica under conditions of free availability of soluble $\mathrm{P}\left(\mathrm{KPO}_{4} \mathrm{H}_{2}\right)$ and available $\mathrm{N}$ $\left(\left(\mathrm{NH}_{4}\right)_{2} \mathrm{SO}_{4}\right)$ (Table 1), either using glucose or glycerol as C-source. Expression of PQQ-GDH led to gluconic acid production in cultures with glucose using TCP as the sole P-source both in the presence of available $\mathrm{N}$ or BNF conditions and also in cultures with soluble $\mathrm{P}$ under BNF conditions (Table 1). Production of gluconic acid concomitantly led to significant appearance of soluble $P$ in supernatants of TCP containing cultures. A significant $P Q Q-G D H$ activity was detected in media containing glycerol and TCP, but $P$ solubilization could not be observed because of the absence of organic acids derived from PQQ-GDH activity (Table 1 ). GaDH activity was observed under all tested conditions suggesting that it is synthesized constitutively but 2-ketogluconate was consistently undetectable irrespective of the growth conditions. Soluble $P$ concentration of negative controls (noninoculated TCP containing media) remained almost constant (between 2 and $8 \mathrm{mg} \mathrm{L}^{-1}$ ) along the experiment.

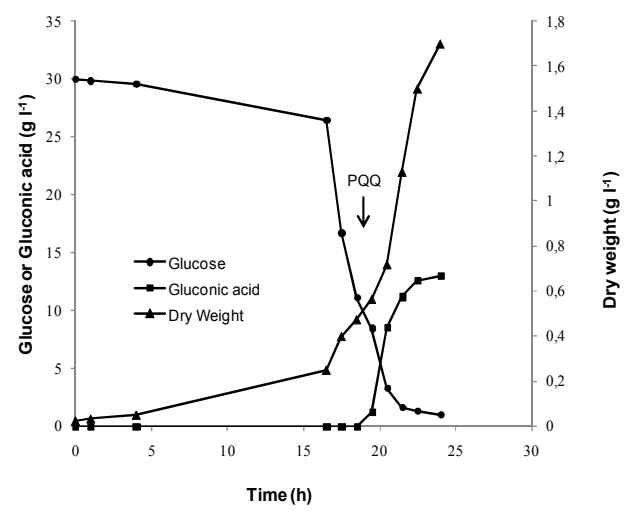

Fig. 1. Gluconic acid, glucose and dry weight of $B$. tropica Mto-293 cultures growing with glucose $30 \mathrm{~g} \cdot \mathrm{L}^{-1}$, P soluble and non-BNF at controlled $\mathrm{pH}$, before and after an instantaneous addition of PQQ. Data are mean of at least three replicates

Table 1. PQQ-GDH and GaDH activities, gluconic acid and soluble $P$ of $B$. tropica Mto-293 cultures growing under different conditions

\begin{tabular}{|c|c|c|c|c|c|c|}
\hline & $\begin{array}{l}\text { Culture medium } \\
\text { supplemented with } \\
\left(\mathrm{g} \mathrm{L}^{-1}\right)\end{array}$ & PQQ-GDH $^{1 *}$ & $\mathrm{GaDH}^{1 *}$ & $\begin{array}{l}\text { Final } \\
\text { gluconic acid } \\
\left(g^{-1}\right)\end{array}$ & $\begin{array}{l}\text { Final } \\
\text { soluble P } \\
\text { (ppm) }\end{array}$ & Final pH \\
\hline No & Glu: $10-\mathrm{KPO}_{4} \mathrm{H}_{2}$ & $\mathrm{ND}^{2}$ & $363 \pm 16$ & ND & - & $2.89 \pm 0.25$ \\
\hline \multirow[t]{4}{*}{ BNF } & Glu: $30-\mathrm{KPO}_{4} \mathrm{H}_{2}$ & $N^{2}$ & $412 \pm 25$ & ND & - & $2.76 \pm 0.15$ \\
\hline & Glu: 30 - TCP & $416 \pm 16$ & $617 \pm 51$ & $14.3 \pm 1.5$ & $40 \pm 5$ & $3.48 \pm 0.12$ \\
\hline & Gly: $30-\mathrm{KPO}_{4} \mathrm{H}_{2}$ & $N^{2}$ & $215 \pm 16$ & ND & - & $6.26 \pm 0.25$ \\
\hline & Gly: $30-\mathrm{TCP}$ & $167 \pm 16$ & $104 \pm 17$ & ND & $<10$ & $6.75 \pm 0.15$ \\
\hline \multirow[t]{6}{*}{ BNF } & Glu: $10-\mathrm{KPO}_{4} \mathrm{H}_{2}$ & $100 \pm 45$ & $450 \pm 63$ & $1.3 \pm 0.5$ & - & $3.36 \pm 0.15$ \\
\hline & Glu: 10 - TCP & $221 \pm 57$ & $637 \pm 98$ & $4.1 \pm 1.5$ & $32 \pm 2$ & $4.18 \pm 0.12$ \\
\hline & Glu: $30-\mathrm{KPO}_{4} \mathrm{H}_{2}$ & $147 \pm 43$ & $287 \pm 63$ & $4.2 \pm 0.3$ & - & $2.78 \pm 0.15$ \\
\hline & Glu: 30 - TCP & $232 \pm 47$ & $411 \pm 36$ & $10.9 \pm 2.9$ & $50 \pm 2$ & $3.69 \pm 0.12$ \\
\hline & Gly: $30-\mathrm{KPO}_{4} \mathrm{H}_{2}$ & $91 \pm 12$ & $218 \pm 23$ & ND & - & $7.05 \pm 0.10$ \\
\hline & Gly: $30-\mathrm{TCP}$ & $107 \pm 14$ & $119 \pm 60$ & ND & $<10$ & $6.85 \pm 0.15$ \\
\hline
\end{tabular}


PQQ-GDH could not be detected (and gluconic acid was not produced) in B. tropica cultures performed with glucose and a soluble P-source under non-BNF conditions, even after the addition of exogenous $P Q Q$ in the reaction mixture of in vitro measurements (Table 1). Nevertheless, an instantaneous addition of $P Q Q$ to those cultures (at controlled $\mathrm{pH}$ ) led to an immediate excretion of gluconic acid (Fig. 1) and a concomitant increase in PQQ-GDH activity from not detected levels to $220 \pm 10$ nmoles reduced DCIP min $^{-1} \mathrm{mg}$ protein ${ }^{-1}$ (assuming $60 \%$ protein content in the biomass). Addition of $\mathrm{CP}$ before the $P Q Q$ pulse led to the same results, indicating that de novo protein synthesis was not a mechanism of PQQ-GDH activity control (data not shown).

\section{DISCUSSION}

As said, most bacteria showing the MPS phenotype convert extracellular glucose rapidly and stoichiometrically to gluconic acid via a PQQ-GDH. This way is considered the main glucose catabolic pathway in these bacteria and normally $P Q Q-G D H$ is expressed constitutively, although modulated by the carbon and energy source requirements [12,30,35]. Our results indicate that the presence of aldoses would be necessary for the activity of the direct oxidative pathway and expression of a MPS phenotype in $B$. tropica, as already reported by Caballero Mellado et al. [16]. On the other hand, batch cultures show that $B$. tropica did not express PQQ-GDH constitutively indicating that, contrary to that reported for other bacteria expressing a strong MPS phenotype [6,36], the direct oxidative pathway is not the primary way of aldose sugars utilization by this bacterium. Only under conditions of $\mathrm{P}$ starvation and/or BNF the direct oxidative pathway could be detected regardless of the carbon source used, glucose or glycerol. In Pseudomonas aeruginosa, PQQ-GDH is not constitutive but inducible by glucose, gluconate, mannitol and glycerol [6]. On the other hand, PQQ-GDH of Enterobacter asburiae, although constitutive, showed a fivefold increase in activity under $P$ starvation but enzyme activity was not completely repressed by the presence of available $P$ in the medium [12]. Goldstein and Liu [37] have reported that the MPS trait in Erwinia herbicola is induced / repressed by low/high levels of exogenous $P$ and found some genes involved on phosphate starvation metabolism. In some microorganisms, the phenomenon of phosphate-starvation-inducible gene expression involves specific phosphate regulated genes and several of these are also inducible by other stress conditions [37]. Therefore, P availability seems to play an important role in regulating $P Q Q-G D H$ expression in some bacteria [38-40] including $B$. tropica, as shown in this work.

The biochemical pathways and genetics of $\mathrm{PQQ}$ GDH synthesis and expression have been studied in many bacteria [32,41,42]. Van Schie et al. [42] showed that the synthesis of PQQGDH holoenzyme and the $\mathrm{PQQ}$ cofactor could be non-coordinated and the control of PQQ-GDH activity by $P Q Q$ synthesis maybe widespread among bacteria. The genes responsible for $P Q Q$ production have been cloned and sequenced in several bacterial genera, including Pseudomonas, Methylobacterium, Acinetobacter, Klebsiella, Enterobacter, and Rahnella [43-46]. Analysis of $P Q Q$ biosynthesis genes from a variety of Gram negative bacteria showed that pqqABCDE genes are conserved, and presence of additional genes is variable [47]. Choi et al. [43] have reported that genes involved in $P Q Q$ biosynthesis can be induced under nutrient limitation. Additionally, overexpression of $p q q$ biosynthetic gene(s) in some bacteria resulted in gluconic acid production and the amount of $P Q Q$, but not apoprotein, limited acid secretion [47]. On the other hand, some reports show that genes which induce MPS ability (in bacteria with MPS negative phenotype) are not directly involved in $P Q Q-G D H$ holoenzyme or $P Q Q$ biosynthesis, but in the synthesis of a transporter protein [48]. In Pseudomona cepacea, another gen called gabY may act as a functional MPS gen in the expression and / or regulation of the direct oxidative pathway [49]. However, the biochemical and genetic mechanisms regulating the biosynthesis of $P Q Q$ and their assembly to give an active PQQ-GDH still remain not clearly known $[47,48,50]$. From our results it seems that $P Q Q-G D H$ expression in $B$. tropica is regulated by the amounts of the cofactor PQQ. But, as shown in the in vitro assays, the presence of $P Q Q$ was not enough to lead to expression of an active PQQ-GDH. Only active growing cultures added with exogenous $P Q Q$ led to expression of $P Q Q-G D H$ in cultures whit soluble $P$ and available N. Cells were not only unable to express PQQ-GDH activity but also needed an active metabolism to produce gluconic acid. It seems that the expression of the direct oxidative pathway in $B$. tropica is not regulated by the induction of holoenzyme synthesis. Nevertheless, some other factor besides the PQQ is necessary in order to detect enzymatic activity. Under either 
$P$ starvation or BNF PQQ synthesis was induced leading to the expression of an active PQQ-GDH.

\section{CONCLUSIONS}

On the basis of these results we conclude that the MPS phenotype already reported for $B$. tropica [16] can be ascribed to the expression of the direct oxidative pathway which involves the expression of an active PQQ-GDH. However, this pathway is not expressed constitutively in this bacterium. Environmental conditions, like low $\mathrm{P}$ and $\mathrm{N}$ availability led to an active extracellular glucose oxidation. Therefore, mineral phosphate solubilization in $B$. tropica involves an inducible pyrroloquinoline quinone-linked glucose dehydrogenase. These findings provide knowledgement about the mechanism and regulation of the mineral phosphate solubilization in B. tropica, and may contribute to the use of this bacterium as plant growth promoting bacteria reducing the dependence on chemical fertilizer.

Further studies using molecular tools are required to continue explaining the complexity of the expression of a MPS phenotype in this bacterium.

\section{COMPETING INTERESTS}

Authors have declared that no competing interests exist.

\section{REFERENCES}

1. Goldstein AH. Bacterial solubilization of mineral phosphates: Historical perspectives and future prospects. Am J Alt Agr. 1986;1:57-65.

2. Rodriguez $H$, Fraga $R$. Phosphate solubilizing bacteria and their role in plant growth promotion. Biotechnol Adv. 1999; 17:319-339.

3. Buch A, Archana G, Naresh Kumar G. Metabolic channeling of glucose towards gluconate in phosphate- solubilizing Pseudomonas aeruginosa P4 under phosphorus deficiency. Res Microbiol. 2008;159:635-642.

4. Crespo JM, Boiardi JL, Luna MF. Mineral phosphate solubilization activity of Gluconacetobacter diazotrophicus under P-limitation and plant root environment. Agri Sci. 2011;2:16-22.

5. Sashidhar B, Podile AR. Mineral phosphate solubilization by rhizosphere bacteria and scope for manipulation of the direct oxidation pathway involving glucose dehydrogenase. J Appl Microbiol. 2010; 109:1-12.

6. Goldstein AH. Recent progress in understanding the molecular genetics and biochemistry of calcium phosphate solubilization by Gram-negative bacteria. Biol Agric Horti. 1995;12:185-193.

7. Han $\mathrm{SH}, \mathrm{Kim} \mathrm{CH}$, Lee JH, Park JY, Cho SM, Park SK, Kim KY, Krishnan HB, Kim YC. Inactivation of pqq genes of Enterobacter intermedium $60-2 \mathrm{G}$ reduces antifungal activity and induction of systemic resistance. FEMS Microbiol Lett 282. 2008;1:140-146.

8. Liu ST, Lee LY, Tai CY, Hung CH, Chang YS, Wolfram JH, Rogers R, Goldstein AH. Cloning of an Erwinia herbicola gene necessary for gluconic acid production and enhanced mineral phosphate solubilization in Escherichia coli HB101: Nucleotide sequence and probable involvement in biosynthesis of the coenzyme pyrroloquinoline quinone. J Bacteriol. 1992; 174(18):5814-5819.

9. Duine JA. Quinoproteins: Enzymes containing the quinonoid cofactor pyrroloquinoline quinone, topaquinone or tryptophan-tryptophan quinone. Eur J Biochem. 1991;200(2):271-284.

10. Anderson DL, Kussow WR, Corey RB. Phosphate rock dissolution in soil: Indications from plant growth studies. Soil Sci Soc Am J. 1985;49(4):918-925.

11. Duff RB, Webley DM, Scott RO. Solubilization of minerals and related materials by 2-ketogluconic acid-producing bacteria. Soil Sci. 1963;95(2):105-114.

12. Gyaneshwar P, Parekh LJ, Archana G., Poole PS, Collins MD, Hutson RA, Naresh Kumar G. Involvement of a phosphate starvation inducible glucose dehydrogenase in soil phosphate solubilization by Enterobacter asburiae. FEMS Microbiol Lett. 1999;171:223-229.

13. Intorne AC, De Oliveira MV, Lima ML, Da Silva JF, Olivares FL, de Souza Filho GA. Identification and characterization of Gluconacetobacter diazotrophicus mutants defective in the solubilization of phosphorus and zinc. Arch Microbiol. 2009;191:477-483.

14. Angus AA, Agapakis CM, Fong $S$, Yerrapragada S, Estrada-De los Santos P, Yang P, Song N, Kano S, Caballero- 
Mellado J, de Faria S, Dakora F, Weinstock G, Hirsch A. Plant-associated symbiotic Burkholderia species lack hallmark strategies required in mammalian pathogenesis. PloS one. 2014;9:e83779.

15. Bernabeu PR, Pistorio M, Torres-Tejerizo G, Estrada-De los Santos P, Galar ML, Boiardi JL, Luna MF. Colonization and plant growth-promotion of tomato by Burkholderia tropica. Sci Hortic. 2015; 191:113-120.

16. Caballero-Mellado J, Onofre-Lemus J, Estrada-De los Santos P, Martínez-Aguilar $\mathrm{L}$. The tomato rhizosphere, an environment rich in nitrogen-fixing Burkholderia species with capabilities of interest for agriculture and bioremediation. Appl Environ Microbiol. 2007;73:5308-5319.

17. Paungfoo - Lonhienne C, Lonhienne TG, Yeoh YK, Webb RI, Lakshmanan P, Chan CX, Lim PE, Ragan MA, Schmidt S, Hugenholtz P. A new species of Burkholderia isolated from sugarcane roots promotes plant growth. Microb Biotechnol. 2014;7:142-154.

18. Bashan $Y$, Holguin $G$. A proposal for the division of "plant growth-promoting rhizobacteria" into two classifications: biocontrol-plant growth-promoting bacteria and plant growth-promoting bacteria. Soil Biol. Biochem. 1998;30:1225-1228.

19. Castro-Gonzalez R, Martinez-Aguilar L, Ramirez-Trujillo A, Estrada-de los Santos $\mathrm{P}$, Caballero-Mellado J. High diversity of culturable Burkholderia species associated with sugarcane. Plant Soil. 2011;345:155169.

20. Luvizotto DM, Marcon J, Andreote FD, Dini-Andreote F, Neves AAC, Araújo WL, Pizzirani-Kleiner AA. Genetic diversity and plant-growth related features of Burkholderia spp. from sugarcane roots. World J Microbiol Biotechnol. 2010; 26(10):1829-1836.

21. Tenorio-Salgado S, Tinoco R, VazquezDuhalt R, Caballero-Mellado J, PerezRueda $E$. Identification of volatile compounds produced by the bacterium Burkholderia tropica that inhibit the growth of fungal pathogens. Bioengineered. 2013; 4:236-243.

22. Nahas E. Factors determining rock phosphate solubilization by microorganisms isolated from soil. World J Microbiol Biotechnol. 1996;12(6):567-572.

23. Lin TF, Huang HI, Shen FT, Young CC. The protons of gluconic acid are the major factor responsible for the dissolution of tricalcium phosphate by Burkholderia cepacia CC-Al74. Bioresource Technol. 2006;97(7):957-960.

24. Song OR, Lee SJ, Lee YS, Lee SC, Kim KK, Choi YL. Solubilization of insoluble inorganic phosphate by Burkholderia cepacia DA23 isolated from cultivated soil. Braz J Microbiol. 2008;39(1):151-156.

25. Reis VM, Estrada-De los Santos $P$, Tenorio-Salgado S, Vogel J, Stoffels M, Guyon S, Mavingui P, Baldani VLD, Schmid M, Baldani JI, Balandreau J, Hartmann A, Caballero-Mellado J. Burkholderia tropica sp. nov., a novel nitrogen-fixing, plant-associated bacterium. Int J Syst Evol Microbiol. 2004;54(6):21552162.

26. Sambrook J, Fritsch EF, Maniatis T. Molecular cloning: A laboratory manual. Cold Spring Harbor Laboratory Press. Cold Spring Harbor, NY; 1989.

27. Stephan MP, Oliveira M, Teixeira KRS, Martínez-Drets G, Döbereiner J. Physiology and dinitrogen fixation of Acetobacter diazotrophicus. FEMS Microbiol Lett. 1991;77:67-72.

28. Nautiyal CS. An effcient microbiological growth medium for screening phosphate solubilizing microorganisms. FEMS Microbiol Lett. 1999;170:265-270.

29. Luna MF, Bernardelli CE, Galar ML, Boiardi JL. Glucose metabolism in batch and continuous cultures of Gluconacetobacter diazotrophicus PAL 3. Curr Microbiol. 2006;52:163-168.

30. Luna MF, Mignone CF, Boiardi JL. The carbon source influences the energetic efficiency of the respiratory chain of $\mathrm{N}_{2}$ fixing Acetobacter diazotrophicus. Appl Microbiol Biot. 2000;54:564-569.

31. Rodriguez H, Gonzalez T, Selman G. Expression of a mineral phosphate solubilizing gene from Erwinia herbicola in two rhizobacterial strains. J Biotechnol. 2000;84:155-161.

32. Clesscerl LS, Greenberg AE, Eaton AD. Standard methods for the examination of water and wastewater APHA-AWWA-WEF. Washington, DC; 1998.

33. Matsushita K, Ameyama M. D-Glucose dehydrogenase from Pseudomonas fluorescens, membrane-bound. Methods Enzymol. 1982;89:149-155.

34. Matsushita K, Shinagawa E, Ameyama M. D-gluconate dehydrogenase from bacteria, 2-keto-D-gluconate-yielding, membrane- 
bound. Methods Enzymol. 1982;89:187193.

35. Goldstein AH, Rogers RD, Mead G. Mining by microbe. Nat Biotechnol. 1993;11(11): 1250-1254.

36. Lesslie TG, Phibbs PV Jr. Alternative pathways of carbohydrate utilization in Pseudomonads. Annu Rev Microbiol. 1984;38:359-387.

37. Goldstein AH, Liu ST. Molecular cloning and regulation of a mineral phosphate solubilizing gene from Erwinia herbicola. Nat Biotechnol. 1987;5(1):72-74.

38. Bernardelli CE, Luna MF, Galar ML, Boiardi JL. Periplasmic PQQ-dependent glucose oxidation in free-living and symbiotic rhizobia. Curr Microbiol. 2001; 42:310-315.

39. Buurman ET, ten Voorde GJ, Teixeira de Mattos MJ. The physiological function of periplasmic glucose oxidation in phosphate-limited chemostat cultures of Klebsiella pneumonia NCTC 418. Microbiol. 1994;140:2451-2458.

40. Goldstein AH, Braverman K., Osorio N. Evidence for mutualism between a plant growing in a phosphate-limited desert environment and a mineral phosphate solubilizing (MPS) rhizobacterium. FEMS Microbiol Ecol. 1999;30:295-300.

41. Naveed M, Sohail Y, Khalid N, Ahmed I, Mumtaz AS. Evaluation of glucose dehydrogenase and pyrroloquinoline quinine (pqq) mutagenesis that renders functional inadequacies in host plants. J Microbiol Biotechnol; 2015. (In press).

DOI: 10.4014/jmb.1501.01075

42. Schie van BJ, Dijken van JP, Kuenen JG. Non-coordinated sythesis of glucose dehydrogenase and its prosthetic group PQQ in Acinetobacter and Pseudomonas species. FEMS Microbiol Lett. 1984;24: 133-138.

43. Choi O, Kim J, Kim JG, Jeong Y, Moon JS, Park CP, Hwang I. Pyrroloquinoline quinone is a plant growth promotion factor produced by Pseudomonas fluorescens B16. Plant Physiol. 2008;146:657-668.

44. Guo YB, Li J, Li L, Chen F, Wu W, Wang J, Wang $\mathrm{H}$. Mutations that disrupt either the pqq or the gdh gene of Rahnella aquatilis abolish the production of an antibacterial substance and result in reduced biological control of grapevine crown gall. Appl Environ Microbiol. 2009;75(21):6792-6803.

45. Han SH, Kim CH, Lee JH, Park JY, Cho SM, Park SK, Kim KY, Krishnan HB, Kim YC. Inactivation of pqq genes of Enterobacter intermedium 60 - $2 \mathrm{G}$ reduces antifungal activity and induction of systemic resistance. FEMS Microbiol Lett. 2008;282(1):140-146.

46. Velterop JS, Sellink E, Meulenberg JJ, David S, Bulder I, Postma PW. Synthesis of pyrroloquinoline quinone in vivo and in vitro and detection of an intermediate in the biosynthetic pathway. J Bacteriol. 1995;177(17):5088-5098.

47. Wagh J, Shah S, Bhandari P, Archana G., Kumar GN. Heterologous expression of pyrroloquinoline quinone (pqq) gene cluster confers mineral phosphate solubilization ability to Herbaspirillum seropedicae Z67. Appl Microbiol Biotechnol. 2014;98(11):5117-5129.

48. Ahmed N, Shahab S. Phosphate solubilization: Their mechanism, genetics and application. Internet $J$ Microbiol. 2009;9:1.

49. Babu-Khan S, Yeo TC, Martin WL, Duron MR, Rogers RD, Goldstein AH. Cloning of a mineral phosphate-solubilizing gene from Pseudomonas cepacia. Appl Environ Microbiol. 1995;61(3):972-978.

50. Rodríguez $H$, Fraga $R$, González $T$, Bashan Y. Genetics of phosphate solubilization and its potential applications for improving plant growth-promoting bacteria. Plant Soil. 2006;287:15-21.

(C) 2016 Bernabeu et al.; This is an Open Access article distributed under the terms of the Creative Commons Attribution License (http://creativecommons.org/licenses/by/4.0), which permits unrestricted use, distribution, and reproduction in any medium, provided the original work is properly cited. http://sciencedomain.org/review-history/13635 